\title{
The investigation of factors affecting the purchasing decisions of consumers of green products
}

\author{
Maryam Jouzdani ${ }^{1}$, Ali Nasr Esfahani ${ }^{2}$
}

${ }^{1}$ Hasht Behesht High Education Institute, Management Department, Isfahan, Iran.

2University of Isfahan, Faculty of Administrative Science and Economic, Isfahan, Iran.

How to cite: Jouzdani, M. and Esfahani, A.N. (2020), "The Investigation of Factors Affecting the purchasing decisions of consumers of green products", Brazilian Journal of Operations \& Production Management, Vol. 17, No. 2, e2020897. https://doi.org/10.14488/BJOPM.2020.015

\section{ABSTRACT}

Goal: The purpose of this study was to investigate the factors affecting the purchasing decisions of consumers of green products.

Design / Methodology / Approach: The sample of this study was composed of consumers of disposable products in Isfahan. In this study, Descriptive statistics is used for data analysis and Structural Equation Modeling is used test the research hypotheses and determine the effect of independent variables on the dependent variable.

Results: Considering the critical values obtained from the research hypothesis test, it can be concluded that environmental protection, environmental responsibility, green product experience, environmentally friendly brands and social acceptance have a positive and significant effect on green product purchase decisions.

Limitations of the investigation: Since the present study is an exploratory study, the findings of the study are limited to the sample and results may be changed if the sample is changed. Also, the sample of green product buyers' decisions was obtained from only one province, so the results may not be generalizable to all provinces of Iran.

Practical implications: According to the results, it is recommended that environment-friendly companies differentiate their products from other products and price them appropriately. This should have an impact on consumers and encourage them to buy and use green products.

Originality / Value: The design of the products in a recyclable form and making their components and materials reusable will in future cause their raw materials are recycled and reused; thus, buyers are more eager to buy green products with regard to environmental protection.

Keywords: Environment; Consumer Behavior; Green Products; Purchasing Decisions.

\section{INTRODUCTION}

An environmentally friendly organization tends to be dependent on the commitment of top management, which ultimately can result in the achievement of an improved competitive advantage) (Spencer et al., 2013). Voluntary pro-environmental behaviors refer to any responsible environmental behaviors that will help achieve environmental sustainability (Norton et al., 2015; Paillé and Boiral, 2013). Over the last few decades, researchers have increasingly focused upon environmental/green marketing which now represents a critical concept in marketing/management literature) Dangelico and Vocalelli, 2017; Polonsky, 2011) Responsibility to environmental issues helps organizations to be competitive and increase their market share. There is evidence that Responsibility increases consumer loyalty (D'Souza et al., 2006). During designing products, Organizations should pay attention to the 
different roles that these products play in different markets and consider the consumer's perceptions about green products. In some markets, such as cleaners and paper products, the extent of changings as a response to environmental challenges is widespread, but it is somewhat more limited in some other markets, such as financial and computer services. Measurement and relative understanding of environment friendly products is also important because in marketing, the good performance of a particular product in a particular market leads not to competitive advantage, but doubtless poor performance can create a strategic risk and result in competitive weakness. The environmental performance of products is affected by many factors and is related to the products of competitors, so the multidimensional analysis of the environmental performance of products is necessary. Hence, green consumption is not only important as a vital issue but also as a long-term trend reflecting changes in social values (Suplico, 2009). Meanwhile, consumers' environmental concerns, aligned with environmental laws, have pushed a large number of companies to design and create environment- friendly products. Hence, companies should significantly reduce their negative environmental impacts in the production, distribution, supply of raw materials and energy consumption. Otherwise, they will be pushed back by strict rules and demanding customers (Grant, 2008). Given the emergence of new trends and approaches to environmental issues, which all indicate the impact of such issues on consumer purchasing behavior, the study of Iranian consumers' attitudes and the level of sensitivity and extent to which they are influenced by their purchasing behavior. Marketing programs seem essential. Therefore, the present study seeks to answer the fundamental questions of whether consumers are sensitive to environmental issues in their consumption. And does this sensitivity influence the shape of their consumption behavior? And the main question of this study is "To what extent do the factors affecting consumer buying decisions affect green consumer buying behavior?" This research, based on past studies, seeks to examine the factors influencing the decision to buy green products in the community. All consumers are not equally interested in buying green products. Therefore, effective marketing of green products seems to be necessary (using targeted marketing strategies instead of mass marketing). The variables of this research are: environmental protection, environmental Responsibility, green product experience, environment- friendly brands and social acceptance. Therefore, the variables presented in Figure 1 are used to investigate the factors influencing consumers' green Purchasing behavior. In fact, Figure 1. Illustrates the conceptual model of this study which is an adaptation of Research by Kumar and Ghodeswar (2015).

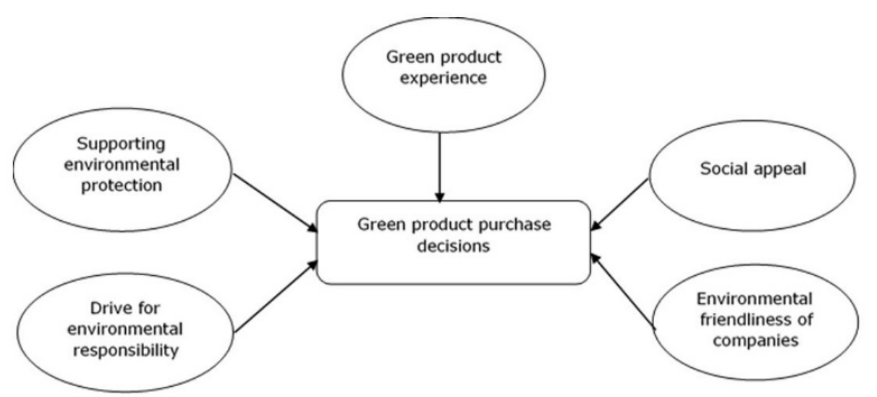

Figure 1: Variables influencing green purchasing decision (Adapted from Kumar and Ghodeswar, 2015).

\section{1-1 Green Marketing}

The term "green marketing" is presently still one of the most discussed topics in the area of academic research (Yadav et al., 2016). In a broader sense, green marketing can be considered to be an outward extension of a firm's environment management systems and procedures, which try to avoid environmental harm and help to safeguard the environment. With environmental issues becoming a significant issue of concern for society, the number of firms relying on environment management systems, standards and audits to achieve sustainable development has increased exponentially (Li et al., 2018). Green marketing is the 
marketing of products designed to protect the environment. Green marketing therefore covers a wide range of activities, such as product modification, process change, packaging change, and advertising reconsideration. Therefore, "green marketing" refers to a concept in which the production, marketing, consumption and disposal of products and services are such that they bring the least harm to nature. Also, with increasing awareness of the implications of global warming, non-degradable waste, the effects of pollutants, etc., marketers and consumers are increasingly sensitive to the use of green products and services (Robinson and Chandran, 2016). The community's concern about the environment has led to the emergence of a new kind of consumer reflecting these concerns in their purchasing decisions. International research also shows that consumers' environmental concerns have led them to gradually change their buying behavior and rethink about the products they buy (Papadopoulos et al., 2010).

\section{1-2 Protecting the Environment}

The implementation of environmental initiatives can help companies adjust their resources (Henri et al., 2016). Firms believe that their image, compliance and prevention of environmental incidents are an important driver of EMS practices. Environmental motivations involving related parties are closely linked with EMSs because they can improve relations with stakeholders (Singh et al., 2015). . Most previous studies, focused on general environmental behavior and did not pay much attention to green purchasing behavior. But as time went on and with the expansion of green marketing, more attention was paid to the behavior of green purchases. (Oliver and Lee, 2010). Although the role of governments and companies in protecting the environment is important and undeniable, but consumers have a much more important role in protecting the environment; in fact, it's the consumer who can help protect the environment by purchasing and using green products. Today we can say that consumers are looking for something more than the products and services. Research has shown that consumers are more concerned with environmental changes and have changed their behavior (Papadulos et al., 2012). According to his research, Suplico)2009(states that $56.55 \%$ of people are relatively aware of environmental issues, which means recognizing and buying environment- friendly products. Today, many consumers are willing to pay more for products that meet environmental standards.

\section{1-3 Environmental Responsibility}

Grant believes (2008) that people's attitudes toward environmental protection are improving. Factors such as increasingly news about environmental pollution, global warming, waste disposal problems, the depletion of the ozone layer and, as a result, increased social pressure play an important role in expanding and publicizing green consumption. Due to Protective behaviors and intent to support environmental measures in the world, sales of green products have increased, and as a result, customers tend to pay more for green products (Chen, 2008a). Green or environmental marketing is a tool for environment- friendly development, and strengthening the image of green products (Khandoker and Mahbubul, 2011). Green consumers strongly believe that the current environmental situation indicates that there are serious and dangerous environmental problems that jeopardize the security of the world. Therefore, one's perception of the severity of the current environmental problems can affect its green purchasing behavior. Customers who have environmental concerns strongly feel that they can control pollution and their buying behavior affects community affairs (Webster Junior, 1975).

\section{1-4 The consuming experience of green products}

The Previous experience of green products is one of the factors affecting consumer's perceived quality regarding these products. The study of consumer's previous experiences is necessary to identify the factors that shape his environmental values. Consumer's previous experiences shape his ideas and values about environment (Kollmuss and Agyeman, 2002). Pickett-Baker and Ozaki (2008) stated that people who have a lot of environmental concerns rely 
on their previous experience in buying. Utman (1998) showed that $41 \%$ of consumers do not buy green products because of their lower perceived quality. In fact, consumers have a negative attitude towards green products and assess their quality lower than non-green products. However, few researchers have investigated the subject of green consumer behavior from the previous experience point of view (Kollmuss and Agyeman, 2002).

\section{1-5 environment- friendly brands}

Trust on Green Products: means satisfaction associated with products, services or a brand that is based on beliefs or expectations that arise from credibility, benevolence and ability regarding environmental performance (Yushen, 2010). Green brands should emphasize the fact that green products performance is similar to that of non- Green products. Green brands should also help the consumers distinguish between green brands and non-green brands with similar performance (Rahbar and Abdul Wahid, 2011). Dangelico and Vocalelli (2017) claimed that the environmental awareness of consumers is higher nowadays, and many brands are competing to increase their share of this new market. Also, consumer concern about the environment has grown steadily in recent years. Considering the growing number of green customers, business leaders are trying to better understand this concept and respond to external pressures regarding environmental concerns (Chen, 2008b). Hartmann et al. (2005) studies have shown that the green brand's functional features leads to more cognitive perception of the brand as an environmentally friendly brand, while emotional features has an important role in branding in relation to the emotional dimension of the brand. The functional and emotional features of green brands have a great positive effect on building a brand attitude. Environmental concern indicates the general familiarity of people with the environment and the extent of their concern about this issue (Choi and Kim, 2005).

\section{1-6 Social Acceptance}

While subjective norms reflect the external social pressure, personal norms, ethical attitudes and behaviors include rules or values that increase motivation (Lin and Huang, 2012). Also, people's attitudes affect their thoughts and feelings, and thus affect their behaviors, including their buying behavior. These indicate that marketers should seek to change the attitudes of consumers and thereby be able to play an effective role in decision making and behavior of consumers (Gonçalves et al., 2015). The acceptance process of a new product requires adaptation among situational characteristics and customer awareness as well as product properties. Looking for new things is a tool for Survival and decision to create a database that is not useful now, but with the assumption that it is important in the future to search for new things, it could be used to improve problem-solving skills (Lin and Huang, 2012).

\section{1-7 purchase decisions}

The decision to buy green purchases is "the likelihood and willingness of a person to achieve products that are compatible with the environment" (Afzal and Israr, 2012; Dehghan and Bakhshandeh, 2014). Indeed, the quality of the green product, clear information about the product, its ingredients, the environment-friendly label, the appearance, as well as product warranty and, generally, consumer insurance, affect the intention to purchase a green product (Maniatis, 2016; Cheng and Chang, 2012) The intention to purchase is an appropriate concept to predict the true buying behavior (Brodowsky, 1996). Beckford et al. (2010) and Chan (2001) found that intention to purchase is a significant predictor of green purchasing behavior. According to the rational action theory, the only fundamental factor before a real behavior is the intention or willingness of a person to do the work, through which it is possible to predict real behavior (Chen and Chai., 2010). The role of behavioral intentions variable is to measure all of the motivational factors that affect a behavior. 


\section{RESEARCH METHODOLOGY}

The statistical population of the study consisted of consumers and buyers of three types of green products that had purchased and consumed these products from green product supply stores over a period of one month. According to the database of green products stores in Isfahan, these individuals were estimated to be more than 100000 people. Based on the number of members of the statistical population, using the Krejcie and Morgan (1970) table and given the 95\% confidence level, 383 members of the statistical population were selected randomly. After determining the sample size of the study, the research questionnaire was distributed among the members of the statistical sample and finally, 380 completed questionnaires were collected. The questionnaire consisted of 24 questions related to the research constructs. To ensure the validity and reliability of the data collection tools, Quantitative and qualitative methods were used to determine the face validity. Qualitative face validity was determined by a panel including 6 Green Product Dealer and 4 Consumer Green Products. These specialists evaluated the level of difficulty, inappropriateness, and ambiguity of the phrases. Their comments were applied in the questionnaire. An impact score was calculated for each question to determine its quantitative face validity. For each of the 24 questions, a 5-point Likert scale was used to determine impact score. This scale range included strongly agree (score 5), agree (score 4), no idea (score 3), disagree (point 2), and strongly disagree (score 1). After completing the questionnaire by the target group, the face validity of the item was calculated by using the Impact Score equation (Neuendorf, 2016).

Impact Score $=$ Frequency $(\%) \times$ Importance.

The Qualitative Content Validity of this questionnaire was reviewed and commented by a panel of experts. For this purpose, the questionnaire was sent to 10 professors and experts in Green products. It was emphasized that they should consider the use of proper words, the importance of the questions and the placement of questions in a proper place. After collecting expert opinion, necessary changes were made to the tool. In order to evaluate the quantitative Content Validity of the questionnaire, the Content Validity Ratio (CVR), was determined by a group of experts (10 people), who examined each question based on a3-item scale including "necessary, useful but not necessary, and not necessary". Then, CVR was calculated according to this formula:

$\left.C V R=\left[\left(n_{e}-N / 2\right)\right) /(N / 2)\right]$ *

Where ne: the number of experts who have chosen the necessary item; $\mathrm{N}=$ Total number of experts. According to the Lawshe table, CVR was considered favorable if it was higher than 0.79 (Lawshe, 1975). In order to evaluate the Content Validity Index (CVI), according to the Waltz and Bausell method, three criteria, including simplicity, specificity and clarity were used for each question, on a4- point scale (Shi et al., 2013). The validity of each question was evaluated by adding the number of experts who had scored the question as 3 or 4, divided by the total number of experts. If this quantity was $\geq 0.79$, the question was acceptable (Waltz and Bausell, 1981). The results of content validity analysis showed that the value of this criterion for the research variables were: Environmental Protection:0.91, Environmental Responsibility: 0.90, Green Product Experience: 0.87, Social Acceptance: 0.93, Eco Friendly Brands: 0.92 and Decision to buy green products: 0.89 Was obtained.

To measure the reliability and consistency of the questionnaire, the most important internal consistency index, Cronbach's alpha test, was used. This test, which yields a coefficient called Cronbach's alpha, is used to test the reliability of the questionnaire designed as a fivepoint Likert scale. If the calculated coefficient is greater than 0.7 , the questionnaire questions have a good internal consistency and are acceptable (Losensky, 2011). In this study, Cronbach's alpha coefficient was used to calculate the reliability of the questionnaire. The results of this test are shown in Table 1. 
Table 1. The results of the Cronbach's alpha test

\begin{tabular}{cc}
\hline Components & the Cronbach Alpha Coefficient \\
\hline Environmental Protection & 0.847 \\
\hline Environmental Responsibility & 0.754 \\
Green Product Experience & 0.711 \\
\hline Social Acceptance & 0.710 \\
\hline Eco Friendly Brands & 0.714 \\
Decision to buy green products & 0.707 \\
\hline
\end{tabular}

The results showed that the Cronbach's alpha coefficients of all components are higher than 0.7 and reliability is confirmed.

In this study, descriptive statistics were used to analyze the data, and in order to test the research hypotheses and determine the impact of independent variables on the dependent variable, inferential statistics (structural equation modeling) were used. The computer software used was SPSS 20 and Amos 20. Structural equation modeling consists of a set of structural equations that describe possible causal relationships between variables. Structural-equation modeling is an extension of factor analysis and is a methodology designed primarily to test substantive theory from empirical data. For example, a theory may suggest that certain mental traits do not affect other traits and that certain variables do not load on certain factors, and that structural equation modeling can be used to test the theory. (A mental trait is a habitual pattern of behavior, thought and emotion.) A structural-equation model (SEM) is a system of linear equations among several unobservable variables (constructs) and observed variables. An SEM is composed of two parts: a structural part, linking the constructs to each other (usually, this part expresses the endogenous or dependant constructs as linear functions of the exogenous or independent constructs), and a measurement part, linking the constructs to observed measurements. The second part resembles a confirmatory factor analysis model. The SEMs can be displayed in visual form - these displays are called path diagrams. The full model is then estimated from a data set and inferences drawn (Sinharay, 2010). These models are often used to test a theory about the relationships between theoretical structures. The Amos software is designed for simple use, and its main feature is that it provides structural equation modeling in a graphical way, so that models can be quickly defined, computed, and easily refined if needed. Amos features an easy-to-use interface for bootstrapping methods, which can be applied to parameter estimates, effect estimates, sample means, sample variances and covariance, correlations, model comparisons, and comparisons of estimation methods. It can accommodate nonrecursive models, models with fixed parameters, and models based on data from multiple populations (Blunch, 2012). Typical output includes variable summaries, assessments of normality, model specification indices, model fit statistics, model parameters, and multiple model comparisons Generally, several indices are used to evaluate model fit, but usually three to five indices are sufficient to confirm the model. These indices are divided into three main groups of absolute fit indices, adaptive fit indices and purposive fit indices, For this purpose, these indicators have been used in this study.

According to the main objective and conceptual model of the research, the hypotheses of this research are as follows:

$\mathrm{H} 1$ : Environmental protection affects purchasing decisions for green products.

H2: Environmental responsibility affects purchasing decisions for green products.

H3: Green product experience affects purchasing decisions for green products.

$\mathrm{H} 4$ : Eco-friendly brand affects purchasing decisions for green products.

H5: Social acceptance affects purchasing decisions for green products.

In this study, Descriptive statistics is used to for data analysis and Inferential statistics (Structural Equation Modeling) is used test the research hypotheses and determine the effect of independent variables on the dependent variable. 


\subsection{The analysis of the demographic characteristics}

this section is intended to describe the data related to the general characteristics of respondents such as Gender and age. For each case, the status of the respondents including frequency, percentage, and cumulative percentage are represented. The results of the analysis of demographic characteristics are shown in Table 2 and Table 3. The results of the analysis of demographic characteristics are shown in Table 2 and Table 3.

Table 2: Frequency distribution of gender variable within the sample

\begin{tabular}{ccc}
\hline $\begin{array}{c}\text { Percentage frequency of each } \\
\text { class }\end{array}$ & The frequency of each class & gender \\
\hline 57.63 & 219 & man \\
42.37 & 161 & Woman \\
\hline $100 \%$ & 380 & Total \\
\hline
\end{tabular}

Table 3: Frequency distribution of the age variable within the sample

\begin{tabular}{ccc}
\hline $\begin{array}{c}\text { Percentage frequency of each } \\
\text { class }\end{array}$ & The frequency of each class & Age \\
\hline 36.32 & 138 & $20-29$ years old \\
\hline 21.32 & 81 & years old30-39 \\
17.89 & 68 & $40-49$ years old \\
13.94 & 53 & $50-59$ years old \\
10.53 & 40 & $60-69$ years old \\
$100 \%$ & 380 & Total \\
\hline
\end{tabular}

\section{DATA ANALYSIS}

In this section, firstly, we investigate the normality of data through Kolmogorov-Smirnov test. Then, the research hypotheses are tested using structural equation model.

\section{3-1 Testing the normality of data.}

To examine the normality of data, the Kolmogorov-Smirnov test (KS) is used. In this test, the null hypothesis is that the distribution of data is Normal.

$\mathrm{HO}$ : the distribution of data is Normal

$\mathrm{H} 1$ : the distribution of data is not Normal.

The Results of Kolmogorov-Smirnov (Table 4) show that the variables in the sample tested are normal Because the significant level is more than $5 \%$ and the null assumption is not rejected. Therefore, to test the hypotheses, parametric statistical tests can be used.

Table 4: The Results of Kolmogorov-Smirnov test

\begin{tabular}{ccccc}
\hline Significance level & $\begin{array}{c}\text { Kolmogorov- } \\
\text { Smirnov test }\end{array}$ & $\begin{array}{c}\text { standard } \\
\text { deviation }\end{array}$ & Mean & Study variables... \\
\hline 0.351 & 0.931 & 0.603 & 4.45 & $\begin{array}{c}\text { Environmental } \\
\text { Protection }\end{array}$ \\
\hline 0.60 & 0.766 & 0.750 & 4.07 & $\begin{array}{c}\text { Environmental } \\
\text { Responsibility } \\
\text { Green Product } \\
\text { Experience }\end{array}$ \\
0.17 & 1.11 & 0.838 & 4.37 & $\begin{array}{c}\text { Social Acceptance } \\
0.51\end{array}$ \\
0.098 & 1.703 & 0.748 & 4.23 & Eco Friendly Brands \\
\hline 0.084 & 3.723 & 1.907 & 4.43 & Decision to buy green \\
products
\end{tabular}




\section{3-2 first order factor analysis}

Before testing the main model and hypotheses, the ability of questionnaire items to measure research variables was investigated using factor analysis. Table 5 exhibits the results of first- order factor analysis of variables using AMOS software based on the research questionnaire.

Table 5: The Results of first -order factor analysis

\begin{tabular}{|c|c|c|c|c|}
\hline result & (p-value) & $\begin{array}{c}\text { Standardized } \\
\text { coefficient }\end{array}$ & $\begin{array}{l}\text { Question } \\
\text { number }\end{array}$ & \\
\hline Appropriate & 0.000 & 0.654 & 1 & \multirow{3}{*}{$\begin{array}{l}\text { Environmental } \\
\text { Protection }\end{array}$} \\
\hline Appropriate & 0.031 & 0.628 & 2 & \\
\hline Appropriate & $\star \star \star$ & 0.592 & 3 & \\
\hline Appropriate & 0.002 & 0.597 & 4 & \multirow{2}{*}{$\begin{array}{l}\text { Environmental } \\
\text { Responsibility }\end{array}$} \\
\hline Appropriate & 0.001 & 0.631 & 5 & \\
\hline Appropriate & $\star \star \star$ & 0.54 & 6 & \multirow{2}{*}{$\begin{array}{l}\text { Green Product } \\
\text { Experience }\end{array}$} \\
\hline Appropriate & $\star \star \star$ & 0.742 & 7 & \\
\hline Appropriate & $\star \star *$ & 0.654 & 8 & \multirow{9}{*}{ Social Acceptance } \\
\hline Appropriate & $\star \star \star$ & 0.708 & 9 & \\
\hline Appropriate & 0.024 & 0.578 & 10 & \\
\hline Appropriate & $\star \star \star$ & 0.615 & 11 & \\
\hline Appropriate & 0.004 & 0.683 & 12 & \\
\hline Appropriate & 0.001 & 0.539 & 13 & \\
\hline Appropriate & $\star \star \star$ & 0.611 & 14 & \\
\hline Appropriate & 0.002 & 0.623 & 15 & \\
\hline Appropriate & $\star * \star$ & 0.558 & 16 & \\
\hline Appropriate & $\star \star \star$ & 0.568 & 17 & \multirow{5}{*}{$\begin{array}{l}\text { environment Friendly } \\
\text { Brands }\end{array}$} \\
\hline Appropriate & $\star \star \star$ & 0.774 & 18 & \\
\hline Appropriate & $\star \star \star$ & 0.845 & 19 & \\
\hline Appropriate & $\star \star \star$ & 0.621 & 20 & \\
\hline Appropriate & $\star \star \star$ & 0.568 & 21 & \\
\hline Appropriate & 0.008 & 0.540 & 22 & \multirow{3}{*}{$\begin{array}{c}\text { Decision to buy green } \\
\text { products }\end{array}$} \\
\hline Appropriate & 0.002 & 0.662 & 23 & \\
\hline Appropriate & $\star \star \star$ & 0.541 & 24 & \\
\hline
\end{tabular}

$\star \star \star$ the significance level (p-value) is less than 0.001 .

it can be concluded that all questions designed to measure the variables are desirable and items are appropriate because all factor loadings are more than 0.5, Table 6 shows the goodness of fit for research variables.

Table 6: goodness of fit for research variables

\begin{tabular}{|c|c|c|c|c|c|c|c|c|}
\hline Measures & CMIN & P-Value & TLI & CFI & RMSEA & PNFI & PCFI & (CMIN/DF) \\
\hline Environmental Protection & 25.36 & 0.093 & 0.971 & 0.912 & 0.068 & 0.696 & 0.568 & 2.909 \\
\hline Environmental Responsibility & 13.641 & 0.073 & 0.978 & 0.993 & 0.071 & 0.593 & 0.548 & 2.928 \\
\hline Green Product Experience & 9.384 & 0.059 & 0.945 & 0.995 & 0.061 & 0.598 & 0.547 & 3.546 \\
\hline Social Acceptance & 4.301 & 0.091 & 0.0973 & 0.972 & 0.072 & 0.599 & 0.582 & 2.956 \\
\hline environment Friendly Brands & 5.354 & 0.056 & 0.976 & 0.935 & 0.057 & 0.548 & 0.741 & 3.845 \\
\hline $\begin{array}{l}\text { Decision to purchase green } \\
\text { products }\end{array}$ & 5.336 & 0.056 & 0.932 & 0.978 & 0.074 & 0.556 & 0.609 & 3.112 \\
\hline Acceptable values & ----- & $\begin{array}{l}\text { Higher } \\
\text { than } 0.05\end{array}$ & $\begin{array}{l}\text { Higher } \\
\text { than } 0.9\end{array}$ & $\begin{array}{l}\text { Higher } \\
\text { than } 0.9\end{array}$ & $\begin{array}{l}\text { Lower } \\
\text { than } 0.08\end{array}$ & $\begin{array}{l}\text { Higher } \\
\text { than } 0.5\end{array}$ & $\begin{array}{l}\text { Higher } \\
\text { than } 0.5\end{array}$ & $\begin{array}{l}\text { Lower } \\
\text { than } 5\end{array}$ \\
\hline
\end{tabular}


According to the Table 6 , it can be concluded that the variables have appropriate goodness of fit.

\section{3-3 Testing the research hypotheses}

Critical value (CR) and P-value are used to Test the research hypotheses. The critical value is obtained by dividing the "regression weight estimation" into "standard error". Regarding significance level of 0.05 , the critical value should be more than 1.96. Critical values Less than 1.96 , the relevant parameter is not considered significant. In addition, P- values less than

0.05 indicate a significant difference of the calculated values for regression weights from zero at the confidence level of 0.95 . In order to assess the research hypotheses, the structural equation model is used (Figure 2).

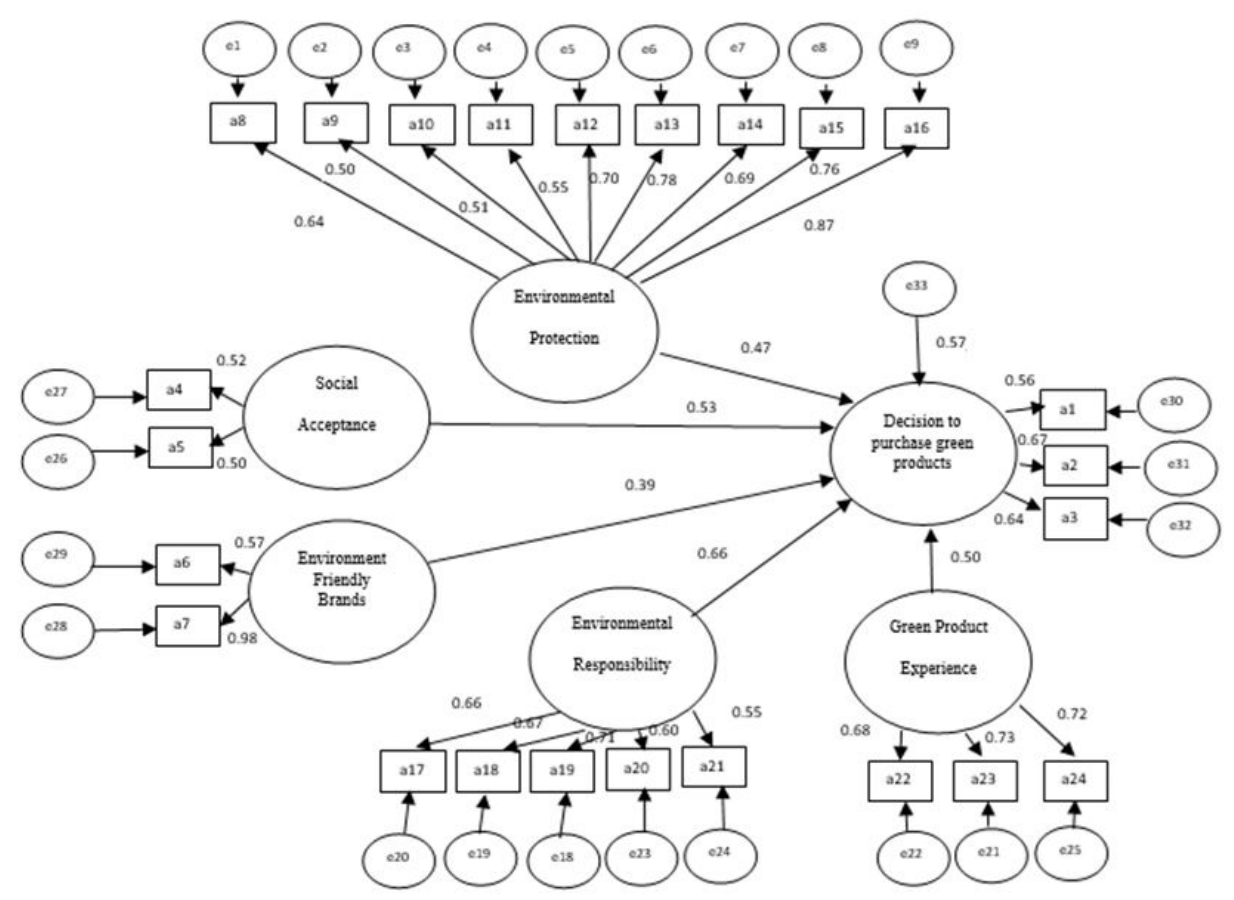

Figure 2: The Structural Equation Modeling.

The hypotheses of the research are shown in Table 7. The fit indices of this model are shown based on three categories: absolute, comparative and parsimonious fit indices. The value of the indices confirms this model.

Table 7: fit indices of the structural equation model

\begin{tabular}{|c|c|c|c|c|}
\hline Result & Index value & $\begin{array}{l}\text { evaluation standard } \\
\text { or critical value for fit }\end{array}$ & Fit Indices & Fit Indices types \\
\hline Goodness of fit is acceptable & $1216 / 61$ & --- & CMIN & \multirow{2}{*}{ Absolute } \\
\hline Goodness of fit is acceptable & 0.059 & Higher than 0.05 & P-Value & \\
\hline Goodness of fit is acceptable & 0.962 & Higher than 0.9 & TLI & \multirow{3}{*}{ Comparative } \\
\hline Goodness of fit is acceptable & 0.908 & Higher than 0.9 & CFI & \\
\hline Goodness of fit is acceptable & 0.078 & Lower than 0.08 & RMSEA & \\
\hline Goodness of fit is acceptable & 0.613 & Higher than 0.5 & PNFI & \multirow{3}{*}{ parsimonious } \\
\hline Goodness of fit is acceptable & 0.713 & Higher than 0.5 & PCFI & \\
\hline Goodness of fit is acceptable & 2.349 & Lower than 5 & (CMIN/DF) & \\
\hline
\end{tabular}


According to Table 7, (the structural equation model of the research hypotheses,) All fit indices are acceptable. In the following, and in Table 8, the results of hypotheses test are presented.

Table 8: The test Results of the hypotheses

\begin{tabular}{cccccc}
\hline Result & value P & $\begin{array}{c}\text { critical } \\
\text { value }\end{array}$ & $\begin{array}{c}\text { path } \\
\text { coefficient }\end{array}$ & Path \\
\hline Confirmed & $\star \star *$ & 5.553 & 0.47 & environmental protection - > Decision to Purchase Green Product & 1 \\
\hline Confirmed & 0.034 & 2.123 & 0.66 & Environmental Responsibility -- > Decision to Purchase Green Product & 2 \\
\hline Confirmed & $\star * *$ & 5.111 & 0.50 & Green Product experience--- > Decision to Purchase Green Product & 3 \\
\hline Confirmed & $\star * *$ & 3.528 & 0.39 & Environment-Friendly Brands -- > Decision to Purchase Green Product & 4 \\
\hline Confirmed & 0.034 & 2.122 & 0.53 & Social Acceptance -- > Decision to Purchase Green Product & 5 \\
\hline
\end{tabular}

***: lower than 0.001

According to path coefficient, critical value and p-value we conclude that all independent variables affect dependent variable (green purchasing decision). Hence, all hypotheses are confirmed. For example, regarding the first hypothesis, one unit of change in environmental protection, changes green purchasing decision by 0.47 units.

\section{4-DISCUSSION AND CONCLUSION}

As it was noted, the studied population was composed of all purchasers and consumers living in Isfahan, Iran. The descriptive findings of the research indicate that the majority of participants are women between the ages of 20 and 29 years old. According to the first hypothesis, we concluded that environmental protection with a path coefficient of 0.47 affects green purchasing decisions. the results of this study are in alignment with the results of Robinson and Chandran (2016), Carman and Cheng (2015), Grimmer et al. (2015), Ritter et al. (2015), Haws et al. (2014). The design of the products in a recyclable form and making their components and materials reusable will in future cause their raw materials are recycled and reused; thus, buyers are more eager to buy green products with regard to environmental protection. According to the second hypothesis of research, environmental responsibility with a path coefficient of 0.66 affects green purchasing decisions; the results of this study are in alignment with the results of Carman and Cheng (2015), Ritter et al. (2015). So it's very important to consider what factors affect consumers in choosing green products. According to the third hypothesis of the research, the results indicate that the green product experience with a path coefficient of 0.50 affects green purchasing decisions. Therefore, it is worth noting that the provision of high quality products, especially in the context of organic products, is very important, and individuals are attracted to high quality and standard products. The results of this study are in alignment with the results of Becker (2010), Wu et al. (2015), Amaran et al. (2014), Kollmuss and Agyeman (2002). Also, based on the fourth hypothesis (environmental friendly brands have an impact on green purchasing decisions) the results show that environment-friendly brands with a coefficient of 0.39 affect green purchasing decisions; it is recommended that Organic / green manufacturing companies must try create a brand and avoid mass marketing and sales. The results of this study are in alignment with the results of Korniawan (2015), Ahmad and Thyagaraj (2015), Wilson (2014). Finally, based on the fifth hypothesis (social acceptance affects purchasing decisions on green products), the results indicate that social acceptance with a coefficient of 0.53 affects green purchasing decisions. The results of this study are consistent with the results of some other studies including Biswas (2016), Gadenne et al. (2011), Zhao et al. (2014), Afzal and Israr (2012). Therefore, it is recommended that environment-friendly companies and organizations, direct the purchase of different sectors of the community and encourages them to buy and use green products by differentiating green products from other products and pricing them appropriately, promoting the benefits of using green products as well as providing discounts for green 
products.The results of the hypothesis test showed that environmental protection, environmental responsibility, and green product experience have a positive impact on green product purchasing decisions. Therefore, it can be said that the design of recyclable goods can be made as components and materials. Their donors will be reused, and in the future will make their raw materials recyclable and reusable rather than discarded (due to non-separation and reuse); thus, buyers will also be given environmental protection. They are more eager to buy green products. Therefore, it is important to consider what factors are important to consumers in choosing green products. The results also indicate that there is a high potential for green products in the community, and consumers and buyers pay particular attention when purchasing natural materials, the positive effects of product performance and energy efficiency, and are willing to pay more for green products. research results showed that there was a positive relationship between eco-friendly brands, social acceptance of customers, and green product purchase decision. Accordingly, it can be argued that companies can appropriately influence consumers by separating green products from other products and pricing them appropriately, and by promoting appropriate advertising and awareness of the benefits of green products as well as granting commercial discounts. Effectively influence the purchase of green goods by purchasing different types of people and encouraging them to purchase and use green goods.

\section{REFERENCES}

Afzal, A. and Israr, A. (2012), "Environment friendly products: factors that influence the green purchase intentions of Pakistani consumers", Pakistan Journal of Engineering, Technology \& Science, Vol. 2, No. 1, pp. 84-117.

Ahmad, A. and Thyagaraj, K.S. (2015), "Consumer's intention to purchase green brands: the roles of environmental concern, environmental knowledge and self expressive benefits", The Journal of World Environ, Vol. 10, No. 3, pp. 879-89.

Amran, H., Wilson, K., Rini, S.S. et al. (2014), "The influence of consumers' perception of green products on green purchase intention", International Journal of Asian Social Science, Vol. 4, No. 8, pp. 924-39.

Becker, C. (2010). Sustainable Packaging: A Comprehensive Approach Towards Sustainable Packaging with a Focus on Primary Packaging of Food and Drinks, Bachelor Thesis in Design Management International, Lucerne University of Applied Sciences and Arts, Lucerne.

Beckford, C.L., Jacobs, C., Williams, N. et al. (2010), "aboriginal environmental wisdom, stewardship, and sustainability: lessons from the Walpole Island First Nations, Ontario, Canada", The Journal of Environmental Education, Vol. 41, No. 4, pp. 239-48.

Biswas, A. (2016), "A study of consumers' willingness to pay for green products", Journal of Advanced Management Science, Vol. 4, pp. 211-5.

Blunch, N. (2012). Introduction to Structural Equation Modeling Using IBM SPSS Statistics and AMOS. SAGE, Thousand Oaks, CA.

Brodowsky, B.G. (1996). The Role of Country of Origin in Consumer Purchase Decisions: Development and Testing of a Comprehensive Theoretical Model, Ph.D. Dissertation, The State University of New York, New York.

Carman, K.M.L. and Cheng, E.W.L. (2015), "Green purchase behavior of undergraduate students in Hong Kong", The Social Science Journal, Vol. 53, No. 2, pp. 67-76.

Chan, R.Y.K. (2001), "Determinants of Chinese consumers green purchase behavior", Psychology and Marketing, Vol. 18, No. 4, pp. 389-413. http://dx.doi.org/10.1002/mar.1013.

Chen, T.B. and Chai, L.T. (2010), "Attitude towards the environment and green products: consumers' perspective", Management Science and Engineering, Vol. 4, No. 2, pp. 27-39.

Chen, Y. and Chang, C. (2012), "Enhance green purchase intentions: the roles of green perceived value, green perceived risk, and green trust", Management Decision, Vol. 50, No. 3, pp. 502-20. http://dx.doi.org/10.1108/00251741211216250.

Chen, Y.Sh. (2008a), "The driver of green innovation and green image: green core competence",Journal of Business Ethics, Vol. 81, No. 3, pp. 531-43. http://dx.doi.org/10.1007/s10551-007-9522-1.

Chen, Y.Sh. (2008b), "The positive effect of green intellectual capital on competitive advantages of firms Yu-Shan Chen", Journal of Business Ethics, Vol. 77, No. 3, pp. 271-86. 
Choi, M. and Kim, Y. (2005), "Antecedents of green purchase behavior: an examination of collectivism, environmental concern, and PCE", Advances in Consumer Research. Association for Consumer Research (U. S.), Vol. 32, No. 1, pp. 592-9.

D'Souza, C., Taghian, M., Lamb, P. et al. (2006), "Green products and corporate strategy: an empirical investigation", Society and Business Review, Vol. 1, No. 2, pp. 144-57. http://dx.doi.org/10.1108/17465680610669825.

Dangelico, R.M. and Vocalelli, D. (2017), "Green marketing: an analysis of definitions, strategy steps, and tools through a systematic review of the literature", Journal of Cleaner Production, Vol. 165, pp. 1263-79.

Dehghan, H. and Bakhshandeh, G. (2014), "The impact of green perceived value and green perceived risk on green purchase behavior of Iranian consumers", International Journal of Management and Humanity Sciences, Vol. 3, No. 2, pp. 1349-57.

Escalas, J. and Bettman, J.R. (2005), "Self-construal, reference groups and brand meaning", The Journal of Consumer Research, Vol. 32, No. 3, pp. 378-89.

Gadenne, D., Sharma, B., Kerr, D. et al. (2011), "The influence of consumers' environmental beliefs and attitudes on energy saving behaviors", Energy Policy, Vol. 39, No. 12, pp. 7684-94.

Gonçalves, H.M., Lourenço, T.F. and Silva, G.M. (2015), "Green buying behavior and the theory of consumption values: a fuzzy-set approach", Journal of Business Research, Vol. 69, No. 4, pp. 1484-1491.

Grant, A.M. (2008), "Employees without a cause: the motivational effects of prosocial impact in public service", International Public Management Journal, Vol. 11, No. 1, pp. 48-66.

Grimmer, M., Kilburn, A.P. and Miles, M.P. (2015), "The effect of purchase situation on realized pro-environmental consumer behavior", Journal of Business Research, Vol. 69, No. 5, pp. 1582-6.

Hartmann, P., Apaolaza Ibáñez, V. and Forcada Sainz, F.J. (2005), " Green branding effects on attitude: functional versus emotional positioning strategies", Marketing Intelligence \& Planning, Vol. 23, No. 1, pp. 9-29.

Haws, K.L., Winterich, K.P. and Naylor, R.W. (2014), "Seeing the world through GREEN-tinted glasses: Green consumption values and responses to environmentally friendly products", Journal of Consumer Psychology, Vol. 24, No. 3, pp. 336-54.

Henri, J.-F., Boiral, O. and Roy, M.-J. (2016), "Strategic cost management and performance: the case of environmental costs", The British Accounting Review, Vol. 48, No. 2, pp. 269-82.

Khandoker, M.R. and Mahbubul, H. (2011), "Exploring price sensitivity of a green brand: a consumers' perspective", World Review of Business Research, Vol. 1, No. 2, pp. 84-97.

Kollmuss, A. and Agyeman, J. (2002), "Mind the gap: why do people act environmentally and what are the barriers to pro-environmental behavior", Environmental Education Research, Vol. 8, No. 3, pp. 239-60.

Krejcie, R.V. and Morgan, D.W. (1970), "determining sample size for research activities", Educational and Psychological Measurement, Vol. 30, No. 3, pp. 607-10. http://dx.doi.org/10.1177/001316447003000308.

Kurniawan, M.P., Chonhenchob, V., Singh, S.P. et al. (2015), "Measurement and analysis of vibration levels in two and three wheel delivery vehicles in southeast Asia", Packaging Technology \& Science, Vol. 28, No. 9, pp. 83650. http://dx.doi.org/10.1002/pts.2143.

Kumar, P. and Ghodeswar, B. (2015), "Factors affecting consumers' green product purchase decisions", Marketing Intelligence \& Planning, Vol. 33, No. 3, pp. 330-47.

Lawshe, C.H.A. (1975), "Quantitative approach to content validity", Personnel Psychology, Vol. 28, No. 4, pp. 563-75.

Li, Y., Ye, F., Sheu, C. et al. (2018), "Linking green market orientation and performance: antecedents and processes", Journal of Cleaner Production, Vol. 192, pp. 924-31.

Lin, P.C.A. and Huang, Y.H. (2012), "The influence factors on choice behavior regarding green products based on the theory of consumption values", Journal of Cleaner Production, Vol. 22, No. 1, pp. 11-8.

Losensky, P. (2011). "11 coordinates in space and time architectural chronograms in Safavid Iran”, in Mitchell, C.P. (Ed.), New Perspectives on Safavid Iran: Empire and Society, Routledge, London, pp. 198.

Maniatis, P. (2016), "Investigating factors influencing consumer decision-making while choosing green products", Journal of Cleaner Production, Vol. 132, pp. 215-28.

Neuendorf, K.A. (2016), The Content Analysis Guidebook, SAGE, Atlanta, GA.

Norton, T.A., Parker, S.L., Zacher, H. et al. (2015), "Employee green behavior: a theoretical framework, multilevel review, and future research agenda", Organization \& Environment, Vol. 28, No. 1, pp. 103-25.

Oliver, J. and Lee, S.-H. (2010), "Hybrid car purchase intentions: a cross-cultural analysis", Journal of Consumer Marketing, Vol. 27, No. 2, pp. 96-103.

Paillé, P. and Boiral, O. (2013), "Pro-environmental behavior at work: construct validity and determinants", Journal of Environmental Psychology, Vol. 36, pp. 118-28. 
Papadopoulos, I., Karagouni, G., Trigkas, M. et al. (2010), "Green marketing: the case of Greece in certified and sustainably managed timber products", EuroMed Journal of Business, Vol. 5, No. 2, pp. 166-90.

Pickett-Baker, J. and Ozaki, R. (2008), "Pro-environmental products: marketing influence on consumer purchase decision", Journal of Consumer Marketing, Vol. 25, No. 5, pp. 281-93.

Polonsky, M.J. (2011), "Transformative green marketing: Impediments and opportunities", Journal of Business Research, Vol. 64, No. 12, pp. 1311-9.

Rahbar, E. and Abdul Wahid, N. (2011), "Investigation of green marketing tools effect on consumers' purchase behavior", Business Strategy Series, Vol. 12, No. 2, pp. 73-83.

Ritter, Á.M., Borchardt, M., Vaccaro, G.L.R. et al. (2015), "Motivations for promoting the consumption of green products in an emerging country: exploring attitudes of Brazilian consumers", Journal of Cleaner Production, Vol. 106, pp. 507-20.

Robinson, M. and Chandran, K. (2016), "Consumer belief and purchase intention towards the green marketing: litrerature review", International Journal for Innovative Research in Science \& Technology, Vol. 2, pp. 200-3.

Shi, J., Mo, X. and Sun, Z. (2013), "Content validity index in scale development", Journal of Central South University Medical Sciences., Vol. 37, No. 2, pp. 152-5.

Singh, N., Jain, S. and Sharma, P. (2015), "Motivations for implementing environmental management practices in Indian industries", Ecological Economics, Vol. 109, pp. 1-8.

Sinharay, S. (2010). "An overview of statistics in education", in Peterson, P., Baker, E. and McGaw, B. (Eds.), International Encyclopedia of Education, 3rd ed., Elsevier, Oxford, pp. 1-11.

Spencer, S., Adams, C. and Yapa, P. (2013), "The mediating effects of the adoption of an environmental information system on top management's commitment and environmental performance, Sustainability Accounting", Management and Policy Journal, Vol. 4, No. 1, pp. 75-102.

Suplico, L.T. (2009), "Impact of green marketing on the students purchase decision", Journal of International Business Research, Vol. 8, No. 2, pp. 71-81.

Tseng, S. and Hung, S. (2013), "A framework identifying the gaps between customers' expectations and their perceptions in green products", Journal of Cleaner Production, Vol. 59, pp. 174-84.

Utman, C.H. (1998), "Performance effects of motivational state: a meta-analysis", Personality and Social Psychology Review, Vol. 1, No. 2, pp. 170-82. http://dx.doi.org/10.1207/s15327957pspr0102_4.

Waltz, C.F. and Bausell, B.R. (1981). Nursing Research: Design Statistics and Computer Analysis. Davis, Philadelphia.

Webster Junior, F.E. (1975), "Determining the characteristics of the socially conscious consumer", The Journal of Consumer Research, Vol. 2, No. 12, pp. 188-96.

Wu, J.-H., Wu, C.-W., Lee, C.-T. et al. (2015), "Green purchase intentions: an exploratory study of the Taiwanese electric motorcycle market", Journal of Business Research, Vol. 24, No. 4, pp. 829-33.

Yadav, R., Kumar Dokania, A. and Swaroop Pathak, G. (2016), "The influence of green marketing functions in building corporate image: evidences from hospitality industry in a developing nation", International Journal of Contemporary Hospitality Management, Vol. 28, No. 10, pp. 2178-96.

Yu-Shan, C. (2010), "The drivers of green brand equity: green brand image, green satisfaction, and green trust", National Yunlin University of Science \& Technology, Vol. 93, No. 2, pp. 307-19.

Zhao, H., Gao, Q., Wu, Y. et al. (2014), "What affects green consumer behavior in China? A case study from Qingdao", Journal of Cleaner Production, Vol. 63, pp. 143-51.

Authors contributions: All the Authors contributed equally to this paper. 